\title{
Praca naukowo-badawcza Wacława Olszewicza i jego wkład w rozwój bibliotekarstwa polskiego
}

\begin{abstract}
W 1900 r. w Warszawie, w wieku 48 lat, zmarł majętny kupiec i przedsiębiorca - inżynier Adolf Olszewicz. Obok swej aktywności zawodowej i skutecznego pomnażania majątku przez całe swe życie oddawał się wielkiej pasji, jaką było kolekcjonowanie książek. W przeciągu kilkudziesięciu lat udało mu się zgromadzić potężny księgozbiór, na który złożyło się kilkanaście tysięcy tytułów w około 20000 tomów. Po jego śmierci ta imponująca kolekcja, stanowiąca jeden z najokazalszych zbiorów prywatnych w Polsce początku XX w., przeszła w spadku na własność jego synów, Wacława i Bolesława Olszewiczów'. Faktyczną opiekę nad zbiorami i ich dalszymi losami przejął jednak starszy z braci, Wacław. Wielki miłośnik książek, humanista, prawnik i ekonomista, badacz kultury, krajoznawca, bibliotekarz i działacz społeczny. Pozostawiona przez ojca ogromna biblioteka, w większości humanistyczna, stała się dla Wacława doskonałym warsztatem naukowym, podobnie jak dla jego brata Bolesława, przyszłego profesora, znanego geografa, historyka geografii, a także bibliofila. Zgromadzone przez A. Olszewicza dzieła ukształtowały jego synów w zakresie zainteresowań naukowych, jak również aktywności społecznej na rzecz tworzenia bibliotek i konsolidacji środowiska bibliotekarskiego w Polsce. Na temat życia i działalności W. Olszewicza powstało kilkanaście artykułów, głównie o charakterze przyczynkarskim, niewyczerpujących jednak tematu. Wciąż odczuwalny jest brak monografii poświęconej tej aktywnej i ważnej postaci polskiego bibliotekarstwa i bibliotekoznawstwa².
\end{abstract}

\footnotetext{
Zob. Informator o stratach bibliotek i księgozbiorów domowych na terytoriach polskich okupowanych w latach 1939-1945 (bez ziem wschodnich), red. nauk. B. Bieńkowska, oprac. U. Paszkiewicz, J. Szymański, Poznań 2000, s. 21; Słownik pracowników książki polskiej. Suplement, pod red. I. Treichel, Warszawa-Łódź 1986, s. 158.

2 Zob. J. Babicz, Z. Wójcik, Olszewicz Wacław (1888-1974), „Kwartalnik Historii Nauki i Techniki” 1975, nr 1, s. 97-103; L. Brożek, Olszewiczowie, „Poglądy” 1975, nr 3, s. 7-8; A. Czech, Sylwetki ślaskich ekonomistów. Wacław Olszewicz, „Dom Ekonomisty” 1997, nr 3-4 (15-16), s. 3951; tenże, Wacław Olszewicz (1888-1974), „Forum” 2011, nr 33, s. 14-20; T. Galińska, Wacław Olszewicz (1888-1974): ,, bibliotekarz z bibliografia w ręku”, Sosnowiec 1989; W. Jabłońska, Wacław Kazimierz Olszewicz. Wspomnienie, „Bibliotekarz” 1975, nr 10, s. 245-247; Z. Janeczek, Siemianowicki stownik biograficzny, Katowice 1996, s. 160; J. Kelles-Krauz, Wactaw Olszewicz (1888-1974),
} 
W. Olszewicz urodził się w 1888 r. w Warszawie. Pomimo przedwczesnej śmierci ojca otrzymał gruntowne wykształcenie, choć nie odbyło się to bez trudności. Edukację rozpoczął od nauki w Gimnazjum Chrzanowskiego w Warszawie, ale już w 1905 r. za udział w strajku szkolnym został wraz ze swym młodszym bratem, Bolesławem, wydalony z gimnazjum $\mathrm{z}$ tzw. wilczym biletem, co było równoznaczne z zamknięciem drogi kształcenia na terenie Królestwa Polskiego. Dzięki determinacji matki Wacław, podobnie jak jego brat, mógł podjąć studia za granicą. Rozpoczął od nauki w Paryżu, na Wydziale Dyplomatycznym Szkoły Nauk Politycznych (École libre des sciences politiques), później zaś kontynuował edukację na Wydziale Nauk Politycznych Uniwersytetu w Brukseli (Université Libre), gdzie uzupełnił wykształcenie w zakresie prawa międzynarodowego i ekonomii, uzyskując tytuł doktora praw na podstawie dysertacji Unia Polski z Litwa - studium z prawa międzynarodowego ${ }^{3}$.

Rozmiłowany w nauce i ukształtowany przez obecne w rodzinnym domu, później zaś odziedziczone książki, tuż po ukończeniu studiów rozpoczął badania historyczne. Jego zainteresowania w tym zakresie wyznaczyły szlak trwającej dwa lata podróży po Europie - odwiedził wówczas Szwajcarię, Włochy i Francję. Skoncentrował się na reformie rządów polskich Jeana Jacques'a Rousseau i kierowany tymi fascynacjami zbliżył się do grona uczonych skupionych w asocjacji Rousseau i ich organie „Annales de la Sociètè Jean Jacques Rousseau", gdzie w 1911 r. opublikował swój pierwszy artykuł naukowy Documents polonais sur J.J. Rousseau et Thérèse Levasseur. Tym zagadnieniom pozostał wierny przez cały okres swej aktywności naukowej, wielokrotnie powracając do publikacji na ten temat, wykorzystując zgromadzone w księgozbiorze oryginalne dzieła J.J. Rousseau oraz ich tłumaczenia, jak np. Wielka rozprawa o nierówności stanów pomiędzy ludźmi w przekładzie Ignacego Skarbka Kiełczewskiego (Warszawa 1819).

We Włoszech W. Olszewicz zajął się poszukiwaniem materiałów dokumentujących związki kulturowe i naukowe Stanisława Augusta Poniatowskie-

\footnotetext{
„Informator Bibliotekarza i Księgarza” 1976, s. 270-274; R. Kotowski, Dziewczynka z obrazu. Historia życia Józi Oderfeldówny, Kielce 2014, s. 58-89; tenże, Lwowska tułaczka Wacława Olszewicza, [w:] Znani i nieznani międzywojennego Lwowa. Studia i materiały, t. 4, red. M. Przeniosło, L. Michalska-Bracha, Kielce 2015, s. 149-161; B. Lopuszański, Wactaw Kazimierz Olszewicz (1888-1974), „Przegląd Biblioteczny” 1975, z. 1, s. 113-115; tenże, Olszewicz Wacław Kazimierz (1888-1974), Wspomnienie, „Studia Historyczne” 1975, z. 2, s. 313-320; tenże, Jeszcze o twórczości naukowej i pisarskiej Wacława Olszewicza, „Studia Historyczne” 1976, R. 19, s. 279-281; tenże, Olszewicz Wactaw Kazimierz (1888-1974), [w:] PSB, t. 24, s. 7-10; J. Reychman, Wacław Olszewicz (23 VII 1888-20 VII 1974), „Kwartalnik Historyczny” 1975, nr 2, s. 512-520; K. Remerowa, Bibliotekarz z bibliografia w ręku - Wactaw Olszewicz, [w:] Portrety bibliotekarzy polskich, Wrocław 1980, s. 258-267; Stownik Pracowników ksiażki polskiej. Suplement, Warszawa-Łódź 1986, s. 159.

3 Zob. A. Czech, Sylwetki ślaskich ekonomistów..., s. 40.
} 
go z ośrodkami zagranicznymi. W 1912 r. w paryskim „Revue des Sciences Politiques" opublikował artykuł o ewolucji polskich konstytucji L'évolution de la constitution polonaise. Efekty tej kwerendy wykorzystał w dalszych wieloletnich badaniach i opracowaniach związanych z działalnością Stanisława Augusta Poniatowskiego ${ }^{4}$.

Po powrocie z naukowej podróży po Europie zamieszkał w Zakopanem, w willi „Ubocz” pod Gubałówką . Tu mógł rozwijać swe pasje związane z bibliotekarstwem i krajoznawstwem. Zaangażował się w działalność Tatrzańskiego Towarzystwa Biblioteki Publicznej i przez pewien czas był zatrudniony w tamtejszej bibliotece. Współpracował ze środowiskiem inteligenckim i patriotycznym, które w latach zaborów skupiało się w Zakopanem bardzo licznie. Zetknął się tam m.in. ze Stefanem Żeromskim ${ }^{6}$. Ale praca bibliotekarza skazywała go również na pośredni kontakt z Włodzimierzem Leninem, bowiem także on znalazł się w gronie czytelników zakopiańskiej biblioteki.

W Zakopanem W. Olszewicz przebywał do 1915 r., kiedy to po opuszczeniu przez Rosjan stolicy wrócił do Warszawy. Tu objął stanowisko bibliotekarza w Bibliotece Ordynacji Krasińskich oraz wiceredaktora „Ekonomisty”, organu Polskiego Towarzystwa Ekonomicznego. Zaangażował się także w działalność społeczną zmierzającą do utworzenia Biblioteki Publicznej m.st. Warszawy oraz organizacji ruchu bibliotekarskiego. Pierwszym krokiem do tego był udział w stworzeniu Wydziału Historii Książnic i Bibliotekoznawstwa Towarzystwa Miłośników Historii, który sfinansował wydanie broszury B. Olszewicza, Polskie zbiory kartograficzne, będącej jedną z ważniejszych publikacji w dziejach polskiego bibliotekarstwa naukowego ${ }^{8}$. Wacław wspólnie $\mathrm{z}$ bratem bardzo aktywnie uczestniczył w organizacji Związku Bibliotekarzy Polskich, współtworząc statut organizacji, który ostatecznie został zatwierdzony w lipcu 1917 r. Na jednym z pierwszych zebrań Związku W. Olszewicz objął kierownictwo Sekcji Bibliotek Naukowych, co pozwoliło mu w pełni oddać się swojej pasji ${ }^{9}$.

4 Zob. W. Olszewicz, Biblioteka króla Stanisława Augusta, „Przegląd Biblioteczny” 1931, z. 1, s. 1-108; tenże, Z dziejów bibliotek i miłośnictwa ksiażek w Polsce w XVIII wieku, „Roczniki Biblioteczne" 1968, R. 12, z. 1-4, s. 51-95; tenże, Biblioteka królewska na Zamku Warszawskim, „Roczniki Biblioteczne” 1969, R. 13, z. 3-4, s. 557-569.

5 Zob. R. Kotowski, Dziewczynka z obrazu..., s. 59.

6 Zob. W. Olszewicz, Stefan Żeromski i biblioteka publiczna w Zakopanem, „Przegląd Biblioteczny" 1966, nr 1-2, s. 51-52; R. Kotowski, Dziewczynka z obrazu..., s. 59.

7 Zob. J. Reychman, dz. cyt., s. 513; J. Babicz, Z. Wójcik, dz. cyt., s. 97; Zob. R. Kotowski, Dziewczynka z obrazu..., s. 59.

8 Zob. B. Olszewicz, Polskie zbiory kartograficzne (próba instrukcji do katalogowania i konserwowania zbiorów kartograficznych), Warszawa 1915.

9 Zob. B. Olszewicz, W. Olszewicz, Z prehistorii Stowarzyszenia Bibliotekarzy Polskich, „Przegląd Biblioteczny” 1967, z. 2, s. 138-143. 
W Warszawie zastał go koniec wojny i odzyskanie przez Polskę niepodległości. Otworzyło to przed nim nowe możliwości zawodowe. Na nowo zaangażował się w pracę państwową, oddał się sprawom polskim i międzynarodowym. Objął kierownictwo Wydziału Ekonomicznego Ministerstwa Spraw Zagranicznych, skąd wyjeżdżał jako kurier polskiego rządu do Paryża na konferencję wersalską - dostarczał w obie strony dokumenty. Przygotowywał materiały dla Delegacji Polskiej na Konferencję Pokojową w Paryżu. Brał również udział w rokowaniach gospodarczych, m.in. z Francją i Włochami. Jako ministerialny urzędnik zetknął się z wieloma politykami, m.in. z premierem Francji Georges'em Clemenceau czy Wojciechem Korfantym. Zaangażował się także w akcję na rzecz przyłączenia Spisza i Orawy do Polski. Z inicjatorem tych działań, ks. Ferdynandem Madeyem, Wacława łączyły bardzo dobre relacje. Obydwaj byli delegatami do Paryża jako doradcy polskiego rządu w sprawie tych terenów. Zetknięcie się podczas konferencji wersalskiej ze sprawami Śląska, powstań śląskich, plebiscytu, było dla W. Olszewicza inspiracją do przyjęcia złożonej w niedługim czasie przez W. Korfantego propozycji wyjazdu na Górny Śląsk i podjęcia tam pracy. Nastąpiło to po likwidacji kierowanej przez Wacława komórki ministerialnej W grudniu $1924 \mathrm{r}^{10}$

Z początkiem 1925 r. objął on funkcję dyrektora polsko-francuskiego banku Banque de Silésie z siedzibą w Katowicach. Po roku pracy w tej instytucji za namową Józefa Kiedronia, dyrektora generalnego Zjednoczonych Hut „Królewska” i „Laura” w Siemianowicach, i jego żony, Zofii Kirkor-Kiedroniowej, Olszewicz przyjął obowiązki prokurenta zarządu tego koncernu. Praca w Siemianowicach nie pociągnęła jednak za sobą rychłego zamieszkania tam. Powodem była konieczność odpowiedniego przygotowania, mieszczącego się na pierwszym piętrze kamienicy przy ul. 3 Maja, siemianowickiego mieszkania pod potężną, skompletowaną i uporządkowaną przez Wacława rodzinną bibliotekę. Adaptacja pokojów i rozpakowanie ponad 100 skrzyń z woluminami wymagały czasu. Ostatecznie wszystkie pomieszczenia mieszkania W. Olszewicza, a zwłaszcza tzw. główny pokój biblioteczny, zostały wypełnione książkami. Regały ustawiono od podłogi po sufit, a mimo to książki musiały być ułożone w dwóch rzędach. Katalogi umieszczono w głębokich szufladach stołów stojących na środku pokoju ${ }^{11}$.

Biblioteka W. Olszewicza w momencie przeprowadzki liczyła ponad 13000 dzieł w ponad 20000 tomów $^{12}$. Była tym samym zasobniejsza od jednej z największych i najcenniejszych w województwie śląskim kolekcji

10 Zob. R. Kotowski, Dziewczynka z obrazu..., s. 63-66.

11 Zob. L. Brożek, Olszewiczowie..., s. 7-8; R. Kotowski, Dziewczynka z obrazu..., s. 63.

12 Zob. tenże, Wspomnienie o bibliotece „Dziedzictwo”, „Biuletyn Informacyjny Biblioteki Śląskiej" 1958, nr 2-3, s. 98. 
książek, której właścicielem był Konstanty Prus. Składało się na nią około 15000 tomów z cennymi drukami i rękopisami, starodrukami i dziełami historycznymi poświęconymi głównie Śląskowi, które w 1924 r. trafiły do Biblioteki Sejmu Śląskiego ${ }^{13}$.

Księgozbiór W. Olszewicza, w przeważającej części humanistyczny, składał się z kilku działów: 1) bibliografii, bibliotekarstwa i bibliotekoznawstwa, 2) krajoznawczego, w którym szczególne miejsce znajdowały stare opisy Polski oraz polonica, 3) historii geografii (w tym 3 polskie wydania Relationi universali... Giovanniego Botera z lat 1609, 1613, 165914, zbiór przeszło 1000 map, m.in. kilka wydań mapy Wacława Grodeckiego Poloniae finitimarumque locorum descriptio ${ }^{15}$, egzemplarz Carte de Pologne... Giovanniego Antonia Rizzi-Zannoniego ${ }^{16}$ ze zbiorów gen. Jana Weyssenhoffa oraz literatura dotycząca historii kartografii powszechnej i polskiej), 4) prawno-socjologicznego, ze szczególnym uwzględnieniem prawa międzynarodowego, 5) historii powszechnej (z listami Aleksandra Chodźki, Henryka Struvego, listem autobiograficznym Władysława Matlakowskiego, notatkami astronomicznymi z wykładów Franciszka Armińskiego na Uniwersytecie Warszawskim w 1826 r. $)^{17}$.

Biblioteka była stale uzupełniana nowymi, nie mniej cennymi nabytkami, jak chociażby dzieła Mikołaja Iorgi, które trafiły do biblioteki W. Olszewicza w związku z jego zainteresowaniami Rumunią i kulturą rumuńską. Wśród nowych tytułów szczególne miejsce zajmowały te poświęcone sprawom Śląska, bowiem nowe miejsce zamieszkania bibliofila obudziło w nim zainteresowania badawcze skupione na historii, kulturze i gospodarce tego regionu oraz jego związkach z innymi krajami. Nie tylko gromadził literaturę w tym zakresie, lecz także sam stał się auto-

13 Zob. W. Pawłowicz, Polonica i silesiaca XVI wieku $w$ zbiorach specjalnych Biblioteki Śląskiej, „Bibliotheca Nostra. Śląski Kwartalnik Naukowy” 2014, nr 4 (38), s. 84; B. Warząchowska, Książka, prasa i biblioteka $w$ działalności Kościoła katolickiego $w$ województwie śląskim (1922-1939), praca doktorska przygotowana pod kierunkiem prof. dr hab. I. Sochy, Katowice 2011, s. 67, [online] <http://www.digitalsilesia.eu/Content/100690/doktorat3184.pdf> (25.11.2016).

14 Giovanni Botero (1544-1617) - słynny włoski pisarz polityczny z przełomu XVI i XVII w. W historii filozofii oraz myśli politycznej G. Botero jest uważany za ucznia Niccola Machiavellego i Jeana Bodina, chociaż nie wpisuje się w ich poglądy. Ponadto był autorem jednego z pierwszych popularnych kompendiów geograficznych, tłumaczonego zarówno na język hiszpański, jak i język polski - zob. G. Botero, Le relationi universali di Giovanni Botero Benese divise in ... quarttro parti..., Vicenza 1595. Wydania polskie - tenże: Relatiae powszechne abo Nowiny pospolite..., Kraków 1609, Kraków 1613; Theatrum świata wszytkiego..., Kraków 1659.

15 Po raz pierwszy wydana ok. 1562 r. w Bazylei.

16 Opracowana w wielkiej skali (1:629 000) mapa Polski Carte de Pologne... - atlas składający się z 24 kart, wydany w Paryżu w 1772 r.

17 Zob. E. Chwalewik, Zbiory polskie. Archiwa, biblioteki, gabinety, galerie, muzea i inne zbiory pamiątek przeszłości w ojczyźnie $i$ na obczyźnie $w$ porządku alfabetycznym wedtug miejscowości ułożone, t. 2: N-Ż, Warszawa-Kraków 1927, s. 410. 
rem wielu cennych opracowań poruszających szereg zagadnień związanych ze Śląskiem: od gospodarki, poprzez politykę po rolę tej dzielnicy w polskiej państwowości. Współpracował z Instytutem Śląskim w Katowicach, gdzie brał czynny udział w wydawaniu „Komunikatu” - biuletynu, na łamach którego publikował swoje prace, m.in. Z dziejów hutnictwa żelaznego na Śląsku w 1935 r. czy też Przemyst górniczo-hutniczy Ślaska wobec Zagtebia Dabrowskiego w okresie okupacji niemieckiej w 1936 r. ${ }^{18}$ Uczestniczył także w opracowaniu zbiorowego wydawnictwa Stan i potrzeby nauki polskiej o Ślasku ${ }^{19}$, gdzie ogłosił artykuł Stan i potrzeby nauki polskiej o Ślasku w zakresie stosunków gospodarczych i społecznych. Ponadto był wiceprezesem Towarzystwa Przyjaciół Nauk na Śląsku, a do wydawanych przez nie „Roczników” pisywał recenzje. Marzeniem W. Olszewicza było, aby znajdowały się tam omówienia wszystkich pojawiających się wydawnictw poświęconych sprawom Śląska. Chętnie też publikował w regionalnym wydawnictwie „Zaranie Śląskie”, gdzie obok wielu recenzji zamieścił w 1935 r. rozprawę Jak pracować naukowo na Śląsku nad zagadnieniami gospodarczymi i społecznymi. Należał również do założycieli Polskiego Towarzystwa Ekonomicznego w Katowicach. W kręgu aktywności W. Olszewicza wciąż jednak pozostawały książki i sprawy związane z ruchem bibliotekarskim. Bibliofil nie skupiał się jedynie na prywatnym księgozbiorze. Poszukiwał możliwości jak najszerszej współpracy, angażując się w działalność założonej w 1937 r. Sekcji Bibliofilskiej Koła Śląskiego Związku Bibliotekarzy Polskich, przekształconej rok później - przy wydatnym udziale Wacława - w samodzielne Śląskie Towarzystwo Miłośników Książki i Grafiki ${ }^{20}$. Zebrania jego członków odbywały się w ich domach, w tym także w mieszkaniu W. Olszewicza $i$ te spotkania należały do najatrakcyjniejszych. Obok ciekawego gospodarza z pewnością wrażenie na zebranych robiła imponująca biblioteka. Podczas jednego z takich posiedzeń, jak wspominał ich bywalec Ludwik Brożek, zapytano W. Olszewicza, jaką książkę ze swojej kolekcji zabrałby ze sobą na bezludną wyspę. Ku zaskoczeniu

18 Zob. Z dziejów hutnictwa żelaznego na Ślasku, „Komunikat Instytutu Śląskiego”, nr 1 i 3 , [online] <http://www.sbc.org.pl/Content/151340/ii2442-1934_1935-01_03a-0001.pdf> (25.11.2016). Zob. też „Komunikat Instytutu Śląskiego”, nr 26, [online] $<\bar{h}$ ttp://www.sbc.org.pl/Content/153692/ ii2442-1936 1937-26-0001.pdf > (25.11.2016).

19 Zob. W. Olszewicz, Stan i potrzeby nauki polskiej o Ślasku w zakresie stosunków gospodarczych i społecznych, [w:] Stan i potrzeby nauki polskiej o Ślasku, red. R. Lutman, Katowice 1936, s. 391-453.

20 Zob. L. Brożek, Śląski ruch bibliofilski, „Zaranie Śląskie” 1938, z. 3, s. 202. Zob. też Statut Śląskiego Towarzystwa Miłośników Ksiązki i Grafiki uchwalony na zebraniu konstytucyjnym dnia 26 kwietnia 1938 roku, Katowice 1998; P. Stasiak, Śląskie Towarzystwo Miłośników Ksiązki i Grafiki (1937-1939), Katowice 1983. 
zebranych, którzy spodziewali się wyboru Biblii lub Pana Tadeusza, bibliofil wskazał Listy do matki Juliusza Słowackiego, czym potwierdził swą wielką wrażliwość i duszę humanisty ${ }^{21}$.

Pomimo zajmowania się z oddaniem sprawami Śląska nie zaniechał W. Olszewicz swych dotychczasowych zainteresowań naukowych i badawczych. Wciąż w kręgu jego uwagi pozostawały zagadnienia związane z krajoznawstwem i historią. Sporo miejsca w pracy bibliofila zajmowały nadal fascynacje Stanisławem Augustem Poniatowskim i jego dworem. Jeden z artykułów poświęcił dyplomacie i mężowi zaufania Stanisława Augusta, Feliksowi Łoyko (także Łojko) ${ }^{22}$. Być może dodatkową inspiracją dla napisania tego artykułu było dla Wacława posiadanie w swych zbiorach rzadkiego osiemnastowiecznego dzieła Łoyki. Jak wspominał Jan Reychman, była to pierwsza odnaleziona książka, która wróciła do rodziny W. Olszewicza $\mathrm{z}$ rozproszonej w okresie II wojny światowej kolekcji ${ }^{23}$.

W. Olszewicz w okresie dwudziestolecia międzywojennego opublikował około 70 artykułów i rozpraw oraz około 50 recenzji. Obok wcześniej wymienionych periodyków publikował m.in. w „Czasopiśmie Geograficznym”, „Ekonomiście”, „Jantarze”, „Przeglądzie Bibliotecznym”, „Rocznikach Dziejów Gospodarczych i Społecznych”, „Strażnicy Zachodniej”, „Ziemi” i innych. Przez cały okres swojej aktywności naukowej wiele miejsca poświęcał zagadnieniom bibliotekoznawczym, publikując artykuły w tym zakresie: Podręczna bibliografia Śląska Górnego w „Ziemi” z 1928 r., Biblioteka króla Stanistawa Augusta w „Przeglądzie Bibliotecznym” z 1931 r., koreferat do referatu Zygmunta Mocarskiego Biblioteki regionalne z uwzględnieniem bibliografii regionalnej w 1932 r. ${ }^{24}$, Bibliografia regionalna w „Zaraniu Śląskim" z 1936 r. Jako znawca zagadnień bibliotekarskich oraz właściciel pokaźnego księgozbioru włączył się także w dyskusję na temat bibliotecznego egzemplarza obowiązkowego, pisząc na łamach „Przeglądu Bibliotecznego” z 1930 r. artykuł Kilka uwag o egzemplarzu obowiazkowym - opowiadał się za przyjęciem odpowiedniego ustawodawstwa bibliotecznego i polityki bibliotecznej zmierzającej do stworzenia sieci książnic prowincjonalnych ${ }^{25}$.

21 Zob. L. Brożek, Olszewiczowie..., s. 8.

22 Zob. W. Olszewicz, Feliks Łoyko, ,Roczniki Dziejów Społecznych i Gospodarczych” 1935, t. 4, s. 105-119.

23 Zob. J. Reychman, dz. cyt., s. 516.

24 Zob. Z. Mocarski, Biblioteki regionalne z uwzględnieniem bibliografii regionalnej. Streszczenie referatu [wygłoszonego na III Zjeździe bibliotekarzy polskich], „Przegląd Biblioteczny” 1932, z. 3, s. 154-157; W. Olszewicz, Biblioteki regionalne z uwzględnieniem bibliografii regionalnej. Streszczenie koreferatu [wygłoszonego na III Zjeździe bibliotekarzy polskich], „Przegląd Biblioteczny" 1932, z. 3, s. 157-160.

25 Zob. W. Olszewicz, Kilka uwag o egzemplarzu obowiązkowym, „Przegląd Biblioteczny” 1930, z. 2, s. 167. 
W sierpniu 1939 r. Wacław otrzymał propozycję objęcia stanowiska dyrektora Departamentu Górnictwa i Hutnictwa w Ministerstwie Przemysłu i Handlu. Przyjęcie tego awansu oznaczało konieczność opuszczenia Śląska i przeprowadzkę do Warszawy, gdzie od 1 września miał rozpocząć urzędowanie.

Gdy W. Olszewicz opuszczał siemianowickie mieszkanie, zabrał ze sobą część wartościowych przedmiotów, ale nie mógł wziąć wszystkiego. W kamienicy przy ul. 3 Maja pozostawił mnóstwo pamiątek rodzinnych, cennych przedmiotów, obrazów, jak również swój ogromny księgozbiór. Bibliofil nie był w stanie w tamtym momencie przewidzieć, co stanie się z jego rodzinną biblioteką. Już w pierwszych miesiącach po wybuchu wojny Niemcy niemalże w całości zniszczyli księgozbiór, paląc tysiące tomów. Z kolekcji pozostało bardzo niewiele książek. Część z nich trafiła w ręce przypadkowych znalazców, a dzięki temu do biblioteki w Bytomiu, by ostatecznie w liczbie niespełna 300 mogły, zgodnie z wolą prawowitego właściciela, zostać oddane, mieszkającej w Siemianowicach, córce W. Olszewicza, Hannie Szaneckiej ${ }^{26}$. Za jej sprawą dzisiaj w Bibliotece Śląskiej można zetknąć się z pozycjami pochodzącymi z ogromnej, przedwojennej kolekcji jej ojca.

Wraz z wybuchem wojny życie W. Olszewicza i jego rodziny, podobnie jak milionów Polaków, uległo całkowitej zmianie. Planowane objęcie przez niego dyrektorskiego stanowiska w ministerialnym departamencie w obliczu zagrożenia wojennego nie mogło oczywiście dojść do skutku. Zamiast tego W. Olszewicz oddelegowany został służbowo do Krzemieńca, gdzie z grupą specjalistów oraz studentami geologii miał zająć się przygotowaniem budowy kopalni węgla. Przewidywano, że wojna spowoduje utrudnienia w dostępie do węgla górnośląskiego, stąd poszukiwano innych źródeł pozyskania surowca. W podróż na wschodnie rubieże w tych niezwykle burzliwych czasach zabrał ze sobą najbliższe osoby - żonę Józefę ${ }^{27}$ i dziewiętnastoletnią córkę Hannę. W Krzemieńcu, gdzie dotarli po kilku dniach podróży zastał ich początek sowieckiej okupacji. Wacław stanął przed koniecznością podjęcia decyzji o dalszych krokach. Rozważał, czy wracać do Warszawy, emigrować wraz z wieloma przedstawicielami rządu, czy też poszukiwać innego możliwie bezpiecznego miejsca. Ostatecznie jednak W. Olszewicz nie zdecydował się na włączenie się w mający miejsce we wrześniu 1939 r. exodus Polaków do Rumunii. Zdecydował się na powrót do Warszawy, jednak tego pomysłu nie udało się już zrealizować. Po kilkunastodniowej tułaczce i wielu perypetiach 13 października dotarł do Lwowa. Tu dzięki licznym

26 Archiwum Rodzinne Janiny Szaneckiej, Pokwitowanie odbioru księgozbiorów Olszewiczów, Bytom 26 IV 1947.

27 Żoną W. Olszewicza była Józefa Oderfeldówna słynna Dziewczynka w czerwonej sukience z obrazu Józefa Pankiewicza - na jej temat zob. więcej: R. Kotowski, Dziewczynka z obrazu..., Kielce 2014. 
znajomościom Wacław, którego dotychczasowa praca, a także osiągnięcia zawodowe i bibliofilskie znajdowały tu duże uznanie, dość szybko otrzymał zatrudnienie w Zakładzie Narodowym im. Ossolińskich. Pomimo zmieniających się w zastraszającym tempie okoliczności kierownictwo starało się utrzymywać działalność tej szczególnej polskiej placówki nauki i kultury.

W okresie okupacji niemieckiej ze względów bezpieczeństwa Wacław zmuszony był na pewien czas zrezygnować z pracy w bibliotece, by wrócić tam, ale już nieoficjalnie. Obostrzenia skierowane przeciwko ludności pochodzenia żydowskiego wykluczały jego formalne zatrudnienie. W oficjalnych spisach pracowników Zakładu Ossolineum W. Olszewicz figurował jako osoba nieżyjąca. Obok nazwiska cyrylicą zapisano krótką notatkę: „помер"28.

Ukrywając się okresowo w pomieszczeniach magazynowych Biblioteki, w tzw. kamienicy sapieżyńskiej przy ul. Stefanyka 11, W. Olszewicz z żoną szczęśliwie przetrwali najtrudniejszy okres II wojny światowej, kiedy działalność Ossolineum była bardzo utrudniona. Pracownicy biblioteki stanęli przed potężnym zadaniem uporządkowania zbiorów, a przede wszystkim ratowania śladów polskiej kultury. Jednym z najbardziej zaangażowanych w ten proces był W. Olszewicz, który w tej pracy upatrywał sens dalszego życia, i bezgranicznie poświęcił się walce o ratowanie dla Polski lwowskich dóbr kultury. Naciski na ludność polską ze strony władz radzieckich, mające na celu zmuszenie jej do opuszczenia miasta, były coraz silniejsze. Fakt, że mimo trudnych warunków bytowych Wacław zdecydował się na pozostanie we Lwowie, świadczy o jego niezwykłej determinacji i odwadze. Trwał na swoim stanowisku pracy i chronił zbiory najdłużej, jak to tylko było możliwe. Umowy z Ukrainą i Białorusią przewidywały, że od 15 września do 15 października 1944 r. przeprowadzona zostanie rejestracja osób chętnych do przesiedlenia, a sama operacja potrwa od 15 października 1944 r. do 1 lutego 1945 r. W. Olszewicz wraz z najbliższymi współpracownikami należał do grupy osób, które „bojąc się zaszkodzić sprawie Biblioteki”, aż do ostatniej chwili, kiedy istniała jeszcze możliwość wyjazdu do Polski, nie zarejestrowały się. Znaleźli się w tym gronie także: Mieczysław Gębarowicz, Janina Kelles-Krauz i Kazimierz Giebułtowski. Ich niezłomna postawa powodowana była poczuciem odpowiedzialności za powierzone zbiory i przekonaniem, że opuszczenie miasta mogłoby ułatwić Ukraińcom działania zmierzające do powolnego, acz systematycznego niszczenia książek, a także kwestionowania polskich praw do zbiorów lwowskich ${ }^{29}$.

${ }^{28}$ Archiwum Lwowskiej Biblioteki Narodowej Ukrainy im. W. Stefanyka, Spis pracowników Lwowskiej Biblioteki Akademii Nauk USRR, ark. 1, sygn. 3896.

29 Zob. M. Matwijów, Walka o lwowskie dobra kultury w latach 1945-1948, Wrocław 1996, s. $44-46$. 
Sytuacja Wacława, podobnie jak większości pracowników Ossolineum, przedstawiała się źle, zwłaszcza w świetle zbliżającego się, przesuniętego na czerwiec 1946 r., ostatecznego terminu zakończenia akcji repatriacyjnej. Nie wyrażając chęci wyjazdu, pozbawił się szans na powrót do kraju. Pracownicy biblioteki i przyjaciele z Polski próbowali w tej sprawie szukać pomocy u Jerzego Borejszy, ówczesnego działacza politycznego i kulturalnego. W. Olszewiczowi sugerowano, by zadeklarował jednak chęć przesiedlenia, co pozwoliłoby na rozpoczęcie starań w Ministerstwie Oświaty o mianowanie jego i M. Gębarowicza delegatami spraw bibliotecznych i rewindykacyjnych. Takie pełnomocnictwo umożliwiłoby Wacławowi pozostanie mimo rejestracji we Lwowie i dało względne poczucie bezpieczeństwa ${ }^{30}$. Nie skorzystał z tego. Działał z zapałem i ogromnym zaangażowaniem, wbrew wszystkim i wszystkiemu postanowił dokończyć to, czego się podjął.

Prace związane z porządkowaniem bibliotecznych magazynów prowadzono do końca lata 1945 r. Efekty tych działań w dużej mierze były zasługą i dziełem W. Olszewicza i coraz mniejszej już grupy Polaków, stopniowo wypieranych przez pracowników pochodzenia ukraińskiego. W 1946 r. Polacy stanowili już tylko 15 procent ogółu zatrudnionych. Kierownictwo biblioteki i aktyw partyjny szybko zorientowali się, że ci, którzy zostali, nie działają w interesie ZSRR, lecz przede wszystkim - Polski, chcąc wysłać do kraju jak największą liczbę książek. Stałe manifestowanie niechętnego stosunku do radzieckiej rzeczywistości w końcu również przyniosło konsekwencje. Uznanych za wrogi element poddano szczególnej obserwacji. W maju 1949 r. w dawnej książnicy Ossolineum, przemianowanej na Bibliotekę Akademii Nauk USRR, komisja międzybiblioteczna przeprowadziła kontrolę działalności. W jej wyniku W. Olszewicz, zaliczony do grona szczególnie reakcyjnych pracowników, został zdegradowany ze stanowiska kierownika Oddziału Czytelników i Magazynów na stanowisko kierownika Gabinetu Literatury Dziecięcej ${ }^{31}$. Wkrótce zaś, za udostępnianie zakazanej literatury, przesunięto go na jeszcze niższe stanowisko - bibliografa w Okręgowym Bibliotecznym Kolektorze ${ }^{32}$.

Dopiero trzy lata później W. Olszewicz został ponownie zatrudniony przez Akademię Nauk USSR jako bibliotekarz na Wydziale Ekonomiki Instytutu Nauk Społecznych, gdzie pozostał do emerytury. Przez cały okres pobytu we Lwowie z różną intensywnością kontynuował swą pracę naukową, poświęcając się bez reszty swej ulubionej dziedzinie - historii kultury i biblioteko-

30 Zob. tamże, s. 53.

31 Zob. tenże, Mieczysław Gębarowicz 1893-1984. Uczony i opiekun narodowych dóbr kultury, Warszawa 2013, s. 281.

32 Zob. A. Czech, Sylwetki śląskich ekonomistów..., s. 49. 
znawstwu. Zbiory Ossolineum towarzyszyły mu do końca jego życia. Były jego miejscem pracy i warsztatem naukowym. W pewnym sensie zastępowały bibliofilowi przedwojenny, bezpowrotnie utracony księgozbiór rodzinny. W. Olszewicz wciąż utrzymywał żywe kontakty z polskim środowiskiem naukowym, śledząc dokonania swych kolegów, czasem nawet recenzując wybrane prace. Ostatnie lata życia spędził na zgłębianiu swych ulubionych tematów, związanych z epoką stanisławowską i krajoznawstwem. Opublikował kilka artykułów poświęconych tym zagadnieniom. Skupił się również na ludziach książki. Ogłosił kilka szkiców i przyczynków do biografii wybranych postaci, m.in. Ludwika Bernackiego, K. Giebułtowskiego, Józefa Łozińskiego, Józefa Pawlikowskiego czy S. Żeromskiego.

W okresie odwilży W. Olszewicz uzyskał upragnione pozwolenie na przyjazd do Polski, dzięki czemu na przełomie lat pięćdziesiątych i sześćdziesiątych mógł kilkakrotnie odwiedzić ojczyznę i swą rodzinę. Zmarł 20 lipca 1974 r., z dala od swych najbliższych, w mieście, do którego rzuciła go historia, a z którym nie potrafił i nie mógł się rozstać. Pochowany został na cmentarzu janowskim we Lwowie ${ }^{33}$.

\section{Streszczenie}

Artykuł dotyczy charakterystyki biograficznej i działalności Wacława Olszewicza (1888-1974), prawnika, ekonomisty, działacza gospodarczego, historyka kultury polskiej, bibliotekarza, bibliotekoznawcy, krajoznawcy, działacza PTK. Wspólnie z bratem, Bolesławem, odziedziczył po swoim ojcu, Adolfie Olszewiczu jeden z największych prywatnych księgozbiorów w początkach XX w. w Polsce. W latach dwudziestych i trzydziestych XX w. obok działalności zawodowej na niwie prawa i ekonomii oddał się aktywności społecznej na polu rozwoju bibliotek i bibliotekarstwa. Jego biblioteka w okresie okupacji niemieckiej została częściowo rozproszona, a w przeważającej części - zniszczona przez Niemców. W. Olszewicz wojnę i okres powojenny spędził we Lwowie, gdzie kontynuował swoją pracę z książkami jako bibliotekarz i bibliograf kolejno w Ossolineum, Ukraińskiej Akademii Nauk i Akademii Nauk ZSRR. Utrzymywał kontakty z polskimi naukowcami, publikował swe prace w polskich czasopismach.

Słowa kluczowe: Wacław Olszewicz - Bolesław Olszewicz - księgozbiór Olszewiczów - Stowarzyszenie Bibliotekarzy Polskich - Towarzystwo

33 Zob. R. Kotowski, Dziewczynka z obrazu..., s. 172. 
Miłośników Książki i Grafiki - Towarzystwo Przyjaciół Nauk na Śląsku Lwów - Śląsk - Siemianowice Śląskie.

\section{Summary}

\section{Wacław Olszewicz's research work and his contribution to the development of Polish librarianship}

The article concerns biographical characteristics and activities of Wacław Olszewicz (1888-1974) - a lawyer, economist, Polish culture historian, librarian and library scientist, Polish Cultural Association (PTK) activist. Together with his brother Bolesław, he inherited one of the largest private collections in the early twentieth century in Poland from his father, AdoIf Olszewicz. In 1920s and 1930s, apart from his professional activities as a lawyer and economist, he devoted himself to community activities in the field of libraries and librarianship development. During the German occupation his library was partially dispersed and most of the collection was destroyed by the Germans. W. Olszewicz spent war and post-war period in Lviv, where he continued his work with books as a librarian and bibliographer in Ossolineum, Ukrainian Academy of Sciences and the Academy of Sciences of the USSR. He maintained contact with Polish scientists, publishing his works in Polish journals.

Key words: Wacław Olszewicz - Boleslaw Olszewicz - Olszewicz Library

- Polish Librarians Association - Society of Friends of Books and Graphics - Society of Friends of Science in Silesia - Lviv - Silesia - Siemianowice Śląskie. 